\title{
Replacement of Fish Meal by Alternative Protein Sources in Rainbow Trout Diets*:
}

\author{
Takeshi Watanabe,* Juadee Pongmaneerat, ${ }^{* 2,3}$ Shuichi Sato, *2 \\ and Toshio Takeuchi*:? \\ (Received March 25, 1993)
}

\begin{abstract}
The utilization of some alternative protein sources, i.e. defatted soybean meal (SBM), corn gluten meal (CGM), and meat meal (MM), as a partial replacement for fish meal was studied with rainbow trout having an average body weight of about $3 \mathrm{~g}$. The combination of those protein meals was used to replace $55,64,73,82$, and $91 \%$ of fish meal in the control diet containing $42 \%$ protein. Duplicate tanks of fish were fed to satiation at $15^{\circ} \mathrm{C}$ for 13 weeks.

Fish fed all the SBM, CGM, and MM combination diets produced a good growth rate, feed efficiency, and voluntary food intake comparable to the control group. Although the PER values of the experimental diets containing alternative protein sources were lower than that of the control, there was no marked difference in protein and energy retention except for the $91 \%$ fish meal replaced diet. However, this diet still seemed to be economically beneficial as a relief for a short supply of fish meal. All the test proteins were well digested, assimilation values ranging from 91 to $93 \%$. Hepatosomatic index and chemical composition of the whole body did not vary from the control group.
\end{abstract}

Soybean meal is one of the most promising replacements for fish meal. However, high levels of soybean meal as a partial or total replacement for fish meal generally reduce feed utilization and result in growth performances lower than those of fish meal diets. ${ }^{1-s}$ ) Soybean meal is considerably high in its content of complex carbohydrates which are poorly digested by rainbow trout, leading to a reduced digestible energy (DE) content in the diet. ${ }^{3)}$ This protein meal has a poorer balance of essential amino acids (EAA) than fish meal, and is somewhat deficient in some certain EAAs such as methionine. Consequently, some researchers have tried to utilize alternative proteins by complementing them with other protein sources so as to obtain the required EAA profile for fish. The combination of soybean meal and corn gluten meal has been employed with success to replace up to $63 \%$ of fish meal in the diet for rainbow trout.s) The use of soybean meal with corn also makes an excellent feed for poultry. ${ }^{*}$ These results have indicated that alternative proteins must be combined with each other for effective utilization in terms of an improved amino acid profile and an elevated dietary protein level.

From these viewpoints, the combination of defatted soybean meal, corn gluten meal, and meat meal were combined as a replacement for fish meal in the diet for rainbow trout.

\section{Materials and Methods}

\section{Experimental Diets}

Commercial brown fish meal, meat meal (MM), and corn gluten meal (CGM) were obtained from Nippon Nosan Kogyo Co.; defatted soybean meal (SBM) was provided by Sakamoto Fish Feed Company. The proximate composition and amino acid contents of these protein meals are presented in Table 1. The composition and nutrient contents of the experimental diets are given in Table 2. SBM was used in combination with CGM and $\mathrm{MM}$ as a protein substitution for

*1 Oral presentation at the annual meeting of the Japanese Society of Scientific Fisheries, Tokyo, April, 1992.

*2 Department of Aquatic Biosciences, Tokyo University of Fisheries, Konan, Minato, Tokyo 108.

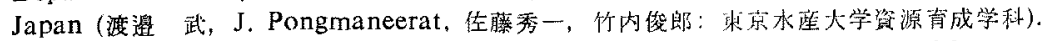

*3 Present address: National Institute of Coastal Aquaculture, Koa-seng, Muang, Songkhla 90000, Thailand. 
Table 1. Amino acid and proximate composition of various protein meals

\begin{tabular}{|c|c|c|c|c|}
\hline $\begin{array}{c}\text { Amino acid } \\
(\mathrm{g} / 100 \mathrm{~g} \text { protein })\end{array}$ & Fish meal & Soybean meal & $\begin{array}{c}\text { Corn gluten } \\
\text { meal }\end{array}$ & Meat meal \\
\hline Arginine & 5.35 & 7.04 & 3.03 & 6.45 \\
\hline Lysine & 7.63 & 5.88 & 1.62 & 5.07 \\
\hline Histidine & 2.90 & 2.58 & 1.81 & 1.93 \\
\hline Phenylalanine & 3.80 & 4.83 & 6.19 & 3.24 \\
\hline Tyrosine & 3.01 & 2.96 & 4.72 & 2.21 \\
\hline Leucine & 7.05 & 7.31 & 15.95 & 5.75 \\
\hline Isoleucine & 3.90 & 4.35 & 3.89 & 2.81 \\
\hline Methionine & 2.63 & 1.32 & 2.37 & 1.39 \\
\hline Cystine & 0.86 & 1.41 & 1.72 & 0.74 \\
\hline Valine & 4.91 & 4.52 & 4.31 & 4.31 \\
\hline Alanine & 5.93 & 4.12 & 8.30 & 7.81 \\
\hline Glycine & 5.99 & 4.07 & 2.50 & 12.40 \\
\hline Proline & 4.11 & 5.04 & 9.82 & 7.97 \\
\hline Glutamic acid & 11.56 & 16.72 & 21.27 & 10.87 \\
\hline Serine & 3.74 & 4.72 & 4.94 & 3.43 \\
\hline Threonine & 3.99 & 3.70 & 3.28 & 3.09 \\
\hline Aspartic acid & 8.69 & 10.99 & 6.07 & 7.12 \\
\hline Tryptophan & 1.03 & 1.28 & 0.42 & 0.65 \\
\hline \multicolumn{5}{|c|}{ Proximate composition $(\%)$} \\
\hline Crude protein & 67.64 & 47.46 & 63.95 & 79.65 \\
\hline Crude lipid & 9.45 & 1.97 & 3.17 & 11.82 \\
\hline Crude ash & 15.14 & 5.59 & 1.54 & 4.38 \\
\hline Moisture & 8.16 & 12.13 & 10.62 & 4.30 \\
\hline
\end{tabular}

Table 2. Composition and nutrient analysis of the experimental diets containing alternative protein sources for rainbow trout

\begin{tabular}{|c|c|c|c|c|c|c|}
\hline Replacement of fish meal (\%) & 0 & 55 & 64 & 73 & 82 & 91 \\
\hline \multirow{2}{*}{ Ingredient $(\%)$} & \multicolumn{4}{|c|}{ Diet no. } & \multirow[b]{2}{*}{5} & \multirow[b]{2}{*}{6} \\
\hline & 1 & 2 & 3 & 4 & & \\
\hline Brown fish meal & 56 & 25 & 20 & 15 & 10 & 5 \\
\hline Meat meal & - & - & 5 & 10 & 15 & 15 \\
\hline Corn gluten meal & - & 15 & 15 & 15 & 15 & 15 \\
\hline Soybean meal & - & 25 & 25 & 25 & 25 & 30 \\
\hline Feed oil*1 & 15 & 15 & 15 & 15 & 15 & 15 \\
\hline$\alpha$-Starch & 15 & 12 & 12 & 12 & 12 & 12 \\
\hline Cellulose & 6 & - & - & - & - & - \\
\hline Mineral mixture*: & 5 & 5 & 5 & 5 & 5 & 5 \\
\hline Vitamin mixture*: & 1.4 & 1.4 & 1.4 & 1.4 & 1.4 & 1.4 \\
\hline Choline chloride & 0.5 & 0.5 & 0.5 & 0.5 & 0.5 & 0.5 \\
\hline Vitamin E ( $50 \%$ purity) & 0.1 & 0.1 & 0.1 & 0.1 & 0.1 & 0.1 \\
\hline Chromic oxide*3 & 1 & 1 & 1 & 1 & 1 & 1 \\
\hline \multicolumn{7}{|c|}{ Nutrient content ( $\%$ on dry matter basis) } \\
\hline Moisture & 4.1 & 5.0 & 4.5 & 6.3 & 7.5 & 7.9 \\
\hline Crude protein & 41.6 & 43.1 & 43.4 & 44.0 & 44.7 & 43.5 \\
\hline Crude lipid & 22.8 & 21.3 & 21.4 & 22.1 & 21.7 & 20.6 \\
\hline Crude ash & 13.1 & 10.0 & 9.4 & 8.9 & 8.5 & 7.9 \\
\hline Crude starch & 14.2 & 17.7 & 20.3 & 21.7 & 22.7 & 23.7 \\
\hline Gross energy*4 & 545.8 & 564.3 & 565.6 & 572.2 & 580.7 & 582.5 \\
\hline Digestible energy* & 478.0 & 486.7 & 499.8 & 499.6 & 508.9 & 519.6 \\
\hline Protein cost ( $¥ / \mathrm{kg}$ protein) & 192.2 & 137.5 & 129.6 & 121.9 & 114.4 & 106.5 \\
\hline $\begin{array}{l}\text { Protein cost } / \text { weight gain } \\
\text { ( } ¥ \text { protein cost } / \mathrm{kg} \text { gain) }\end{array}$ & 68.4 & 49.6 & 46.9 & 44.8 & 43.1 & 42.6 \\
\hline \multirow{2}{*}{\multicolumn{7}{|c|}{$\begin{array}{l}\text { *1 A mixture of pollack liver oil: soybean oil }(2: 3) \text {. } \\
\text { *2 The composition was the same as reported previously.5) } \\
* 3 \text { Chromic oxide: cellulose }(1: 1) \text {. }\end{array}$}} \\
\hline & & & & & & \\
\hline \multicolumn{7}{|l|}{ ** kcal $/ 100 \mathrm{~g}$ dry diet. } \\
\hline
\end{tabular}


Table 3. Amino acid composition of the experimental diets containing alternative protein sources for rainbow trout

\begin{tabular}{|c|c|c|c|c|c|c|c|}
\hline \multirow{2}{*}{$\begin{array}{l}\text { Amino acid } \\
(\mathrm{g} / 100 \mathrm{~g} \text { dry diet })\end{array}$} & \multicolumn{6}{|c|}{ Diet no. } & \multirow{2}{*}{$\begin{array}{l}\text { Requirement*1 } \\
\text { (g/100g protein) }\end{array}$} \\
\hline & 1 & 2 & 3 & 4 & 5 & 6 & \\
\hline Arginine & 2.21 & 2.25 & 2.36 & 2.38 & 2.43 & 2.45 & $3.1(1.34 / 40)$ \\
\hline Lysine & 3.14 & 2.39 & 2.38 & 2.25 & 2.19 & 2.10 & $4.7(1.88 / 40)$ \\
\hline Histidine & 1.17 & 1.10 & 1.11 & 1.07 & 1.04 & 1.03 & $1.4(0.46 / 40)$ \\
\hline Phenylalanine & 1.60 & 2.08 & 2.11 & 2.06 & 2.05 & 2.09 & $2.8(1.12 / 40)$ \\
\hline Tyrosine & 1.12 & 1.44 & 1.44 & 1.39 & 1.38 & 1.38 & $1.9(0.76 / 40)$ \\
\hline Leucine & 2.93 & 4.14 & 4.18 & 4.08 & 4.06 & 4.10 & $3.9(1.56 / 40)$ \\
\hline Isoleucine & 1.69 & 1.79 & $1.8 \mathrm{I}$ & 1.74 & 1.72 & 1.71 & $2.1(0.84 / 40)$ \\
\hline Methionine & 1.13 & 0.97 & 0.93 & 0.89 & 0.91 & 0.81 & $1.6(0.64 / 40)$ \\
\hline Cystine & 0.37 & 0.55 & 0.55 & 0.54 & 0.58 & 0.56 & $0.8(0.31 / 40)$ \\
\hline Valine & 2.08 & 2.06 & 2.10 & 2.06 & 2.06 & 2.04 & $2.8(1.12 / 40)$ \\
\hline Alanine & 2.42 & 2.59 & 2.74 & 2.77 & 2.87 & 2.79 & \\
\hline Glycine & 2.52 & 1.99 & 2.37 & 2.66 & 2.99 & 2.86 & \\
\hline Proline & 1.68 & 2.43 & 2.64 & 2.78 & 2.95 & 2.99 & \\
\hline Glutamic acid & 4.81 & 6.69 & 6.85 & 6.77 & 6.77 & 7.02 & \\
\hline Serine & 1.52 & 1.86 & 1.90 & 1.84 & 1.86 & 1.88 & \\
\hline Threonine & 1.64 & 1.59 & 1.62 & 1.54 & 1.53 & 1.51 & $3.0(1.20 / 40)$ \\
\hline Aspartic acid & 3.63 & 3.77 & 3.84 & 3.72 & 3.69 & 3.72 & \\
\hline Tryptophan & 0.49 & 0.42 & 0.42 & 0.40 & 0.38 & 0.38 & $0.4(0.16 / 40)$ \\
\hline EAAI*2 & 79.07 & 77.76 & 77.71 & 74.92 & 73.89 & 74.90 & \\
\hline
\end{tabular}

fish meal. Diet 1 was the control diet, containing $56 \%$ fish meal as its sole protein source. The combination of these protein meals was used to replace $55,64,73,82$, and $91 \%$ of fish meal in the control diet for diets $2,3,4,5$, and 6 , respectively. The diets were formulated to contain almost the same levels of protein but a slightly higher energy content (GE) in diets with higher levels of fish meal replacement in order to compensate for undigestible carbohydrates in plant ingredients. The amino acid composition and EAA index of the diets are presented in Table 3. All the experimental diets seemed to contain sufficient amounts of EAA to meet the requirement of this fish. The amino acid content in fish meal replaced diets was almost comparable to that in the control fish meal diet, except for lysine and methionine. However, the lysine level in these diets ( $>2.1 \%$ of dry diet) was over the requirement value of $1.88 \%$ of dry diet for rainbow trout reported by $\mathrm{Ogino}^{7}$ or $1.3 \%$ of dry diet recently reported by $\mathrm{Kim}$ et al. ${ }^{8}$ Methionine requirement for this fish has been reported to be about $1 \%$ of dry diet in the absence of dietary cystine, ${ }^{\theta 3}$ or $0.64 \%$ when dietary cystine was $0.32 \%{ }^{7}$ Therefore, all the experimental diets contained a sufficient amount of this EAA. EAA index was calculated on the basis of the EAA of the whole egg protein. The value varied between 74 to 79 , being highest in the control diet.

The dietary ingredients were well mixed with a commercial mixer, and oil was gradually added to the dry mix and enough water added to make a stiff dough. The mixture was passed through a meat chopper and noodle-like pellets were cut into a suitable size. Then they were dried in a vacuum dryer at $20^{\circ} \mathrm{C}$ for $18-24$ hours. The diets were kept in the refrigerator $\left(3^{\circ} \mathrm{C}\right)$ until use.

\section{Fish and Feeding Methods}

The stock rainbow trout were initially fed a commercial rainbow trout diet for 4 weeks. Fish with an average body weight of about $3 \mathrm{~g}$ were randomly selected and 30 fish each were placed into $45 l$ tanks. Water temperatue was controlled at $15 \pm 1^{\circ} \mathrm{C}$ and water supply was maintained at $0.6-1.07 / \mathrm{min}$. Each diet was fed to fish in duplicate, twice a day at satiation level for 13 weeks. During the feeding period, they were weighed at 4-week intervals in order to record the growth rate.

\section{Analytical Methods}

The diets were sampled and analyzed for crude 
protein, crude lipid, crude starch, crude ash, moisture, and gross senergy. ${ }^{10}$ Feces samples were analyzed for chromic oxide, crude protein, crude starch, and gross energy. ${ }^{103}$ The amino acid composition of the experimental diets was determined by Japan Food Research Laboratories. Digestibility was determined using chromic oxide as the inert reference substance. Feces were collected using the same method as mentioned previously. ${ }^{103}$

Fifty fish were initially sampled and fifteen from each tank were finally sampled for proximate analysis. Pooled whole body samples from each tank were analyzed for protein, lipid, moisture, and ash using the same methods as described elsewhere. ${ }^{10)}$

\section{Statistical Analysis}

The analysis of variance (ANOVA) and Duncan's multiple range test were applied to compare the differences of treatment means at the 0.05 significance level.

\section{Results and Discussion}

\section{Growth and Feed Performances}

The growth and feed utilization are given in Table 4. The average body weight of fish fed different diets during a period of 13 weeks is shown in Fig. 1. Fish fed a diet containing $25 \% \mathrm{SBM}$ and $15 \% \mathrm{CGM}$, replacing $55 \%$ of fish meal, showed the best growth rate. The replacement of fish meal up to $82 \%$ with various combinations of SBM, CGM, and MM produced slightly higher growth than the control fish meal diet. But the growth was slightly reduced when $91 \%$ of the fish meal was substituted by $30 \% \mathrm{SBM}$, $15 \% \mathrm{CGM}$, and $15 \% \mathrm{MM}$. However, the final body weight and percent weight gain of fish receiving this diet was not significantly different from

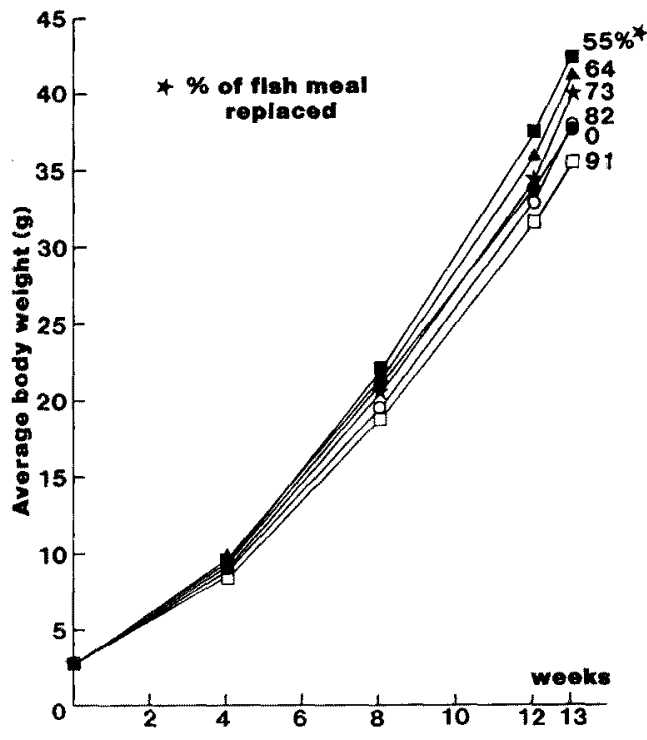

Fig. 1. Growth of rainbow trout fed diets containing soybean meal, corn gluten meal, and meat meal as a substitute for fish meal.

that fed the fish meal diet. Feed efficiency was between 1.1 and 1.2, being lowest in the $91 \%$ fish meal replaced diet. The PER of all the experimental diets was high, ranging from 2.5 to 2.8. These values tended to decrease slightly when the fish meal substitution level increased. The lower feed and protein utilization of fish fed the $91 \%$ replaced diet may possibly be due to lower amino acid absorption. This was supported by the results of Wilson et al.,11) who reported that individual amino acid availabilities within a feed ingredient are variable, although there was reasonable agreement between protein digestibility values and average amino acid availability values. They also noted that the lysine availability value of $90.9 \%$ is somewhat higher

Table 4. Growth, feed efficiency, and PER of rainbow trout fed diets containing alternative protein sources

\begin{tabular}{ccccccc}
\hline Diet no. & $\begin{array}{c}\text { Replacement } \\
\text { of fishmeal } \\
(\%)\end{array}$ & $\begin{array}{c}\text { Av. body wt. (g) } \pm \text { SD } \\
\text { Initial }\end{array}$ & Final & $\begin{array}{c}\text { Weight } \\
\text { gain } \\
(o \sigma)\end{array}$ & $\begin{array}{c}\text { Feed } \\
\text { etficiency }\end{array}$ & PER \\
\hline 1 & 0 & $3.0 \pm 0.4$ & $37.5 \pm 13.5^{\mathrm{a} * 1}$ & $1166.8^{\mathrm{a}}$ & 1.17 & 2.81 \\
2 & 55 & $2.9 \pm 0.4$ & $42.3 \pm 14.1^{\mathrm{a}}$ & $1355.3^{\mathrm{a}}$ & 1.19 & 2.77 \\
3 & 64 & $2.9 \pm 0.3$ & $41.1 \pm 12.1^{\mathrm{a}}$ & $1314.7^{\mathrm{a}}$ & 1.20 & 2.76 \\
4 & 73 & $2.9 \pm 0.3$ & $39.9 \pm 10.1^{\mathrm{a}}$ & $1287.4^{\mathrm{a}}$ & 1.20 & 2.72 \\
5 & 82 & $2.9 \pm 0.3$ & $37.9 \pm 12.1^{\mathrm{a}}$ & $1226.6^{\mathrm{a}}$ & 1.19 & 2.66 \\
6 & 91 & $3.0 \pm 0.4$ & $35.3 \pm 9.7^{\mathrm{a}}$ & $1093.3^{\mathrm{a}}$ & 1.10 & 2.50 \\
\hline
\end{tabular}

*1 Values with the same superscript within columns are not significantly different at $P>0.05$. 
Table 5. Feed consumption and retention of protein and energy in rainbow trout fed diets with alternative protein sources

\begin{tabular}{|c|c|c|c|c|c|c|c|}
\hline \multirow{2}{*}{ Diet no. } & \multirow{2}{*}{$\begin{array}{l}\text { Replacement } \\
\text { of fishmeal } \\
(\%)\end{array}$} & \multirow{2}{*}{$\begin{array}{l}\text { Feeding } \\
\text { rate } \\
(\%)\end{array}$} & \multicolumn{3}{|c|}{ Daily intake per fish } & \multicolumn{2}{|c|}{ Retention (\%) } \\
\hline & & & Feed (mg) & Protein (mg) & $\mathrm{DE}^{* 1}$ (cal) & Protein & Energy \\
\hline 1 & 0 & 1.70 & 344.5 & 142.9 & 1674 & 44.6 & 47.4 \\
\hline 2 & 55 & 1.70 & 384.0 & 165.2 & 1930 & 45.1 & 48.1 \\
\hline 3 & 64 & 1.68 & 369.8 & 160.5 & 1878 & 44.2 & 47.0 \\
\hline 4 & 73 & 1.67 & 358.0 & 158.3 & 1830 & 42.7 & 45.6 \\
\hline 5 & 82 & 1.68 & 342.3 & 153.6 & 1769 & 41.5 & 44.6 \\
\hline 6 & 91 & 1.79 & 342.0 & 150.5 & 1782 & 38.4 & 41.6 \\
\hline
\end{tabular}

*1 Digestible energy.

than the $80.4 \%$ of methionine availability reported for soybean meal in catfish. Dabrowski et al. ${ }^{2}$ found that amino acid absorption by rainbow trout decreased even when $25 \%$ of the fish meal protein was replaced by soybean meal protein (13\% of soybean meal in diet), and decreased further at the 50 and $100 \%$ substitution levels particularly of methionine, leucine, and threonine. The same authors also found that an average EAA absorption decreased by $9.9 \%$ in fish fed a diet containing $25 \%$ soybean meal $(81.3 \%$ EAA absorption) compared to that fed a fish meal $\operatorname{diet}(91.2 \%$ EAA absorption).

The feed consumption and retention of protein and energy are shown in Table 5. Fish fed all the experimental diets exhibited good feeding activity due to a high palatability of the diets. The daily feed intake of all the experimental fish fed various fish meal replaced diets did not differ greatly from that of the control group. The mean value was about $1.7 \mathrm{~g} / 100 \mathrm{~g}$ body wt./day. This result indicates that a combination of SBM, CGM, and MM as a replacement for $91 \%$ of fish meal could produce feed palatability comparable to the fish meal diet. All the experimental fish exhibited good health, and no mortality was observed throughout the feeding period. Lovell reported that SBM could be included as a major protein source in rainbow trout diets with a satisfactory growth rate, but that if the level of fish meal was reduced below approximately $18 \%$, diet palatability decreased. ${ }^{12}$ However, the present study found that only about $5 \%$ fish meal was enough to provide good feed palatability in rainbow trout when $91 \%$ of fish meal was replaced by a combination of $30 \% \mathrm{SBM}, 15 \% \mathrm{CGM}$, and $15 \% \mathrm{MM}$.

The protein and energy retention in fish fed diets in which fish meal was substituted up to $82 \%$ was not apparently different from those fed the fish meal diet. Meanwhile, fish fed the $91 \%$ fish meal replaced diet showed lower protein and energy retention than the control group. The values of protein and energy retention ranged from 38.4 to $45 \%$ and from 41.6 to $48.1 \%$, respectively. All nutrient utilization parameters in fish fed diets in which fish meal was replaced up to $82 \%$ generally revealed good performances comparable to those fed the fish meal diet.

Although these parameters in fish fed the $91 \%$ fish meal replaced diet were inferior to those in fish fed the fish meal diet, the protein cost of feed or the protein cost per $\mathrm{kg}$ weight gain of fish was still lower in the former group than in other groups (Table 2.), when calculated on the basis of the price of each protein ingredient in 1992 (fish meal, $130 / \mathrm{kg}$; SBM, $44.5 / \mathrm{kg}$; CGM, $¥ 58 / \mathrm{kg} ; \mathrm{MM}, ¥ 85 / \mathrm{kg}$ ). The replacement of fish meal up to $91 \%$ by a combination of $30 \% \mathrm{SBM}, 15 \% \mathrm{CGM}$, and $15 \% \mathrm{MM}$ (with $5 \%$ of fish meal in the diet) is therefore economically beneficial.

\section{Apparent Digestibility}

The apparent digestibility of dietary nutrients is presented in Table 6 . The protein digestibility

Table 6. Apparent digestibility of nutrients in diets with various alternative protein sources in rainbow trout

\begin{tabular}{|c|c|c|c|c|}
\hline \multirow{2}{*}{$\begin{array}{l}\text { Diet } \\
\text { no. }\end{array}$} & \multirow{2}{*}{$\begin{array}{l}\text { Replacement } \\
\text { of fishmeal } \\
(\%)\end{array}$} & \multicolumn{3}{|c|}{ Apparent degestibility $(\%)$} \\
\hline & & Protein & Starch & Energy \\
\hline 1 & 0 & 91.2 & 82.9 & 87.7 \\
\hline 2 & 55 & 90.9 & 77.9 & 87.7 \\
\hline 3 & 64 & 91.8 & 79.3 & 88.7 \\
\hline 4 & 73 & 92.3 & 76.7 & 88.2 \\
\hline 5 & 82 & 92.7 & 78.5 & 88.6 \\
\hline 6 & 91 & 93.5 & 79.1 & 89.1 \\
\hline
\end{tabular}


Table 7. Carcass composition of the experimental fish fed diets with various alternative protein sources

\begin{tabular}{crrrrrr} 
Diet no, & $\begin{array}{c}\text { Replacement of } \\
\text { fishmeal }(\%)\end{array}$ & $\begin{array}{c}\text { Crude } \\
\text { protein }\end{array}$ & $\begin{array}{c}\text { Crude } \\
\text { lipid }\end{array}$ & Moisture & Crude ash & $\begin{array}{c}\text { Hepato-somatic } \\
\text { index }\end{array}$ \\
\hline Initial fish & & 14.68 & 5.62 & 78.36 & 2.29 & \\
1 & 0 & 15.77 & 14.25 & 68.74 & 2.03 & 1.05 \\
2 & 55 & 16.15 & 14.63 & 67.90 & 1.99 & 0.95 \\
3 & 64 & 15.89 & 14.14 & 68.65 & 1.97 & 1.05 \\
4 & 73 & 15.64 & 13.82 & 69.16 & 1.93 & 1.05 \\
5 & 82 & 15.55 & 13.69 & 68.78 & 1.99 & 1.03 \\
6 & 91 & 15.31 & 14.08 & 68.51 & 1.98 & 1.00 \\
\hline
\end{tabular}

of all the experimental diets was relatively high, ranging from 91 to $93 \%$, and was not greatly affected by the inclusion of these alternative proteins. The high protein digestibility of 91,89 , and $91 \%$ for SBM, CGM, and MM has been pointed out previously. ${ }^{10,13}$ * The digestibility of starch in the fish meal replaced diets was 76$79 \%$, with no great difference between treatments, except for a slightly higher value in the control diet $(83 \%)$. This could be ascribed to the fact that almost the same amount of plant proteins (25-30\% SBM and 15\%CGM) and undigestible carbohydrates were included in the $55-91 \%$ fish meal replaced diets and that $\alpha$-starch with high digestibility was contained in the control diet. The energy digestibility values of the diets were all high, ranging between 88 to $89 \%$, and were not markedly different in the dietary treatments. The energy digestibility was also not apparently affected by starch digestibility, due to the low dietary starch level.

\section{Body Composition}

The whole body composition and hepatosomatic index (HSI) of all the experimental fish are reported in Table 7. The body protein content of fish fed fish meal replaced diets was not markedly different from fish fed the control diet, except for a slightly lower value in fish fed the $91 \%$ fish meal replaced diet. The protein and lipid contents of the initial fish were lower than those of the final fish after the experiment. The moisture content was higher in the initial fish than the final. The body lipid, ash, and moisture contents of fish fed fish meal replaced diets were not apparently different from those on the control diet. There was no marked difference in HSI between dietary groups. It ranged between
0.95 to 1.05 , which was in accordance with that in other studies, ${ }^{14,18)}$ This HSI may suggest the good condition of the experimental fish. Satomi and Tanaka, 1973 (cited by Dabrowska and Wojno, 1977), ${ }^{18}$ ) using covariance analysis, showed that there was no direct relationship between the relative weight of the liver of trout fed a diet containing soya bean and that of trout fed commercial pelleted feed.

Therefore, it was concluded that a combination of $30 \% \mathrm{SBM}, 15 \% \mathrm{CGM}$, and $15 \% \mathrm{MM}$ as a replacement for about $90 \%$ of fish meal in the diet for rainbow trout produced growth comparable to the fish meal diet at about $44 \%$ dietary protein level. The protein and feed utilization of this diet was somewhat lower than that of the fish meal diet, but the diet is still economically beneficial as a relief for a short supply of fish meal. A combination of these alternative proteins might improve their amino acid profiles, leading to improved feed utilization.

\section{References}

1) M. N. Alexis: Comparative evaluation of soybean meal and carob seed germ meal as dietary ingredients for rainbow trout fingerlings, Aquat. living Resour., 3, 235-241 (1990).

2) K. Dabrowski, P. Poczyczynski, G. Kock, and B. Berger: Effect of partially or totally replacing fish meal protein by soybean meal protein on growth, food utilization and proteolytic enzyme activities in rainbow trout (Salmo gairdneri). New in vivo test for exocrine pancreatic secretion. Aquaculture, 77, $29-49$ (1989).

3) I. G. Fowler: Substitution of soybean and cottonseed products for fish meal in diets fed to chinook and coho salmon. Prog. Fish-Cult., 42, 87-91 (1980).

4) J. W. Andrews and J, W. Page: Growth factors in the fish meal component of catfish diets. J. Nutr., 104, 1091-1096 (1974).

5) J. Pongmaneerat and T. Watanabe: Utilization of soybean meal as protein source in diets for rainbow trout. Nippon Suisan Gakkaishi, 58, 1983-1990 (1992).

6) R. H. Harms: Practical poultry feed formulations based on

*4 J. Pongmaneerat and T. Watanabe: Protein quality of feed ingredients determined in carp and rainbow trout. Abst. of the Meeting of Japan Soc. Sci. Fish., Miyazaki, October, 1989, p. 99. 
essential amino acids and use of soybean meal. Presented at American Soybean Association Seminars in India and Indonesia, April 20-May 3, 1991. ASA Technical Bulletin, PO8, 1991, pp. 1-18.

7) C. Ogino: Requirements of carp and rainbow trout for essential amono acids. Nippon Suisan Gakkaishi, 46, 171$174(1980)$.

8) K. I. Kim, T. B. Kayes, and C. H. Amundson: Requirements for lysine and arginine by rainbow trout (Oncorhynchus mykiss). Aquaculture, 106, 333-344 (1990).

9) M. I. Walton, C. B. Cowey, and J. W. Adron: Methionine metabolism in rainbow trout fed diets of differing methionine and cystine. J. Nutr., 112, 1525-1535 (1982).

10) T. Watanabe and J. Pongmaneerat: Quality evalution of some animal protein sources for rainbow trout Oncorhynchus mykiss. Nippon Suisan Gakkaishi, 57, 495-501 (1991),

11) R. P. Wilson, E. H. Robinson, and W. E. Poe: Apparent and true availability of amino acids from common feed ingredients for channel catfish. $J$. Nutr., 111,923-929 (1981).

12) R. T. Lovell: Use of soybean meal products in diets for aquaculture species: revised. ASA Technical Bulletin, American Soybean Association, Vol. AQ 21-90 6/7, pp. 16 (1990).

13) J. Pongmaneerat and T. Watanabe: Nutritional evaluation of soybean meal for rainbow trout and carp. Nippon Suisan Gakkaishi, 59, 157-163 (1993).

14) M. N. Alexis, E. Papaparaskeva-Papoutsoglou and V. Theochari: Formulation of practical diets for rainbow trout (Salmo gairdneri) made by partial or complete substitution of fish meal by poultry by-products and certain plant byproducts. Aquaculture, 50, 61-73 (1985).

15) H. Dabrowska and T. Wojno: Studies on the utilization by rainbow trout (Salmo gairdneri) of feed mixture containing soyabean meal and an addition of amino acids. Aquaculture, 10, 297-310 (1977). 